\title{
THE AESTHETICS OF NATURE IN THE DRAWINGS OF ANCIENT IRAQI ART
}

\author{
Mahmmoud H. Abdul - Rahman Hussein
}

DOI: $10.37648 /$ ijrssh.v10i03.008

Received: $25^{\text {th }}$ May, 2020; Accepted:18 ${ }^{\text {th }}$ June, 2020; Published: $30^{\text {th }}$ June,2020

\begin{abstract}
This study aims to: Identify the aesthetics of nature in drawings of ancient Iraqi art. It emerged from the theoretical study of this subject that graphic drawings in Iraq are among the oldest arts known to man since the beginning of creation. Where the foundations and civilizational foundations of the entity of civilized societies appeared in the Mesopotamian civilization before all ancient civilizations. The beginnings of the fine arts, such as sculpting, pottery, and engraving on cylindrical seals, drawing, motifs, and colors, were revealed by archeology. Among those arts (the various landscape paintings executed by the ancient Iraqi artist on the walls, clay, crockery, stones, and rocks).
\end{abstract}

Key words: Aesthetics, Nature, Drawings, Ancient, Iraqi, Art.

\section{AN INTRODUCTION}

The Iraqi lowlands between the Tigris and Euphrates rivers are characterized by a fertile plain that made their residents set up urban centers in the midst of these plains. They created huge palaces and fortified castles to face the dangers of invasions, harsh weather, droughts, and predatory wild animal attacks, as well as mastered the construction of temples for worship. Their art reflected their adaptation to and fear of natural forces as well as their military conquests.

Southern Iraq was available as an important clay material in building and making crockery, sculptures and paintings to write on it (clay inscriptions), in addition to wood materials, black basalt stone, sandstone, durite and alabaster used in various sculptures as well as metals such as bronze, copper, gold and silver, as well as pearls and precious stones often It is used for carving artworks, boxes, or musical instruments. The ancient Iraqis used all kinds of stones in their cylindrical seals, such as lapis lazuli, agate, alabaster, and hematite. However, they were to supply some rare stones.

The Sumerians excelled in the arts, especially the plastic arts, including drawing, and their greatest interest in nature was their inspiration. The Acadians and Babylonians followed them, then the Assyrians. The political control of Mesopotamia and its artistic influences extended to neighboring cultures, reaching the Syrian-Palestinian coast. The rest of the peoples that invaded the region adopted the artistic traditions of Mesopotamia. From all this, the research problem formulated by the researcher comes in a question format, as follows:

1) What are the natural topics covered in drawings of the old Iraqi artist?

2) What are the technologies used?

3) Was the human presence a role in these drawings? 
4) Where do the aesthetic features lie?

\author{
The importance of research and the need for \\ it
}

The importance of this research lies in highlighting some aspects that contribute to solving research problems by collecting and linking knowledge, observations and data, leading to innovation and development of solutions and coming up with new results that contribute to providing human libraries with these cognitive values and allow individuals and educational and educational institutions to expand and develop them and may produce Including several cultural studies to study the values, cultural traditions and social methods of different societies and peoples.

\section{Motives for conducting research}

This research is a way to understand the characteristics of ancient Iraqi art, especially those related to natural drawings that embodied reality in all its aspects, which may lead to the discovery of several issues that help to stand in the knowledge of how and the situation that masters the old Iraqi society. This study also assists the researcher in obtaining a new academic qualification in research. Also, this study is considered an intellectual work of special creativity that brings joy and pleasure when arriving at the desired important results that contribute to serving societies and increasing their knowledge.

\section{Research objective}

The current research aims to reveal and demonstrate the aesthetics of nature in drawings of ancient Iraqi art.

\section{search limits:}

Spatial boundaries: Iraq.

Temporal limits: 6000--539 BC. M.

Objective limits: Aesthetic nature in ancient Iraqi art paintings.

\section{HISTORICAL INTRODUCTION}

The first person, since the beginning of his life in the ancient ages that preceded the blogging era, tried to stand on the secrets of nature, being the first and direct influence on him, including his strength and his security, therefore her body is in paintings that are not without beauty, as his view of it was from a magic scene that brings only economic benefit to it, so it was These paintings are a seat of honesty and amazement to this day, especially since they were executed on the walls of caves and their ceilings and on various rocks, and even on bones, shells, ivory, etc. Throughout the ages, these scenes took on a kind of simulation of nature, Sometimes he draws the various animals alone, sometimes he draws the chase by man, and at other times it is in a swamp of water and another in the forests. These scenes were implemented, for example, in various methods such as abstraction or imitation, for nature was almost a speaking area that the first artist transferred to the human civilizations that followed. These types of arts spread in all civilizations, including Mesopotamia (Iraq).

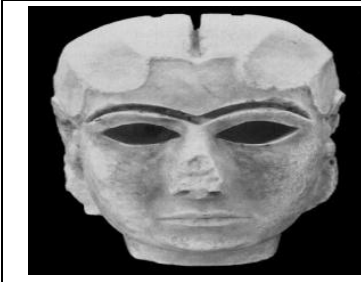

Figure1

https://upload.wikimedi a.org/wikipedia/commo ns/6/6e/UrukHead.jpg

The ancient Iraq witnessed great transformations and artistic developments where the oldest artistic and architectural remains known to date have appeared in it, especially in its north due to the Neolithic period in the hills of Mount Sinjar. Archaeological layers dating back to the ninth millennium BC showed that there are circular structures and huts built of gypsum in which some of the human skulls scattered on the ground may indicate ritual practices that prevailed in that ancient period (Muhammad Ali, 1977, p. 11). 


\section{THE DEVELOPMENT OF ARTS IN ANCIENT IRAQI ART}

Ancient Iraqi art went through several stages since (about $7000 \mathrm{BC}-539 \mathrm{BC}$ ) before the emergence of the writing, where archeology was discovered in the ancient site (Hassouna), which are many houses that contain many examples of painted pottery (Said, 1985). And (the site of Samarra), whose abstract and allegorical designs are of particular religious and sacred importance, and those beautiful drawings were found executed on some pottery vessels dating back to the fifth millennium BC. Among those drawings: a scene of women dancing and forming a circle like a ring and spreading their hair to the side ... and the location of (Tel Halaf), the place where diverse and decorated pottery and statues of seated women were interpreted as the gods of fertility (Kassar, 1988, p. 107). In the south, there appeared (the era of Abeed), whose culture is characterized by decorated black pottery and according to historical sources, the period of slaves belongs to the region of southern Iraq, as this culture began from about $5300 \mathrm{BC}$ and continued until the beginning of the Uruk $4000 \mathrm{BC}$.

Various things related to (Jumada Nasr and al-Warka) also known as the Protoliterate period (approximately 3500-900 BC) could be found in Iraq (Ismail, 1985, p. 221). The limestone temple was the main building at the fifth archaeological level of Warka (about $3500 \mathrm{BC}$ ). Although the superstructure was not maintained, some limestone remains were preserved on a layer of soil that turned out to be a building of huge size properties. Some structures of the fourth level of wark are lined with mosaic made of clay in the form of multi-colored cones and are an integral part of the walls, forming geometric designs. Another technique for decorating was whitening the walls. This led to a building built in Warka dedicated to the Sumerian god Anu known as the (Bit - Res) (Ru, 1986, p. 558), which had a shallow, narrow, and long sanctuary inside. The temple was built at a height of 12 meters from the ground level on a high platform, predicting the typical religious construction of the ancient Iraqis, and it is a zakora stepped tower whose function was to bring the priests or kings closer to the heavenly gods, or to serve as a platform for God descending to communicate with worshipers. Wonderful and beautiful stone statues have been discovered in Warka. The most beautiful of the statues is the head of a woman (fig. 1) or deities made of limestone (3500 - 3000 BC, the National Museum of Iraq, Baghdad), which were supposed to have a decorative graft on the eyebrows, large open eyes, and a deep central thread of hair. The Iraqi National Museum contains what is called the "Warka Vase" (Figure 2) in the same period (350-300 BC), which is a cylindrical shape that is divided into records or horizontal bands. The first upper band depicts a procession in which the king introduces a basket of fruits to the goddess of fertility (enana),

or naked priests carrying performances in the central band and in the lower part there is a row of animals, on top of which are adorned forms of natural plants. Uruk period witnessed (Baqir, 2009, pp. 20-21) The use of cylindrical seals used from stones and is engraved with two types of carving: (bas-relief or relief carving), and are closely related to the clay number. Its

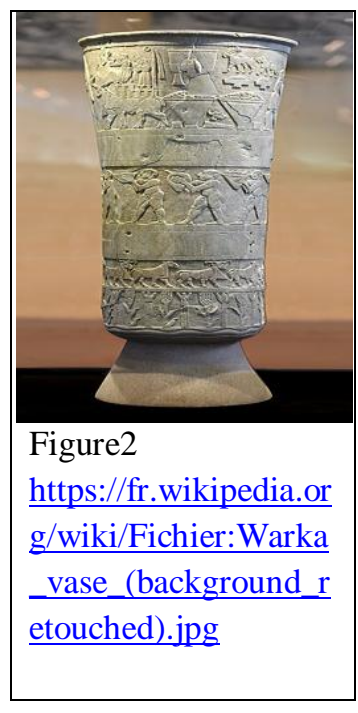


cylindrical shape will remain as a common type of seal in Mesopotamia for 3,000 years as it is used as forms of personal identity letters and documents that are rolled over the wet clay number to obtain a permanent imprint or a symbolic scene in a microcosm. The most important topics or drawings on cylindrical seals are: bulls, priests, or kings with scenes of hunting, wars, or hiking in nature, cattle raising, marine motifs, architecture, lions, complex mythical animals, and other strange shapes. These various animals, whether fictitious or real, were created with a very large vitality, interpreted in a stylized manner. The artists' work on stamping represents an important expression of Iraq's ancient culture and a special characteristic of its distinguished civilization.

\section{CHARACTERISTICS OF ANCIENT IRAQI ARTS UNTIL THE END OF THE BABYLONIAN ERA IN THE YEAR 539 BC.}

A new phase began in $926 \mathrm{BC}$, when Commander Nebubalasir took over Babylon, and ended Assyrian rule He controlled the areas belonging to the Assyrians, and his son, Nebuchadnezzar, took power after him, who was able to expand the country's influence to include Palestine and Syria and that the first people who used the word Syria were the Babylonians (Hati 1958, p. 62), and he imposed a tribute on a number of areas, and subjected the Kingdom of Judah to his rule. And he exiled a number of its inhabitants, as Nebuchadnezzar was concerned with the architectural aspect, they fortified the state of Babylon and established temples, palaces and hanging gardens, and in his reign became one of the most powerful and famous countries in the world (Suse, 1978, pp. 133-146).

The ancient Iraqi arts developed and diversified and reached the height of their greatness from the Neolithic period to the end of the Babylonian era in the year 539 $\mathrm{BC}$, due to the diversity of cultures and civilizations that lived in its land: As the cultures and civilizations of the Sumerians, Acadians, Babylonians, Assyrians, and others. Thanks to the emergence of these many diverse cultures, diverse art and craft materials, shapes and techniques have emerged. The stylistic development in the arts also led to the emergence of different patterns, shapes, and themes used in other periods. The ancient lands of Iraq were rich in mud, among other materials. The old Iraqi environment was characterized by making clay bricks. It is a mixture of clay, straw and glass with other materials such as stone and palm trunks.

The most important reasons that contributed to the development of the arts in ancient Iraq are: Wars, which are a source of permanent concern, so a large amount of skilled arts and artists are devoted to glorifying military victories and methods of preparing military campaigns and showing the role of kings in them. Religion and worship also had an important and significant role in the affairs of the state, and hence the importance attached to religious buildings. Therefore most of the statues were for spiritual purposes. Another reason is the direct effects of the natural environment on the arts and their reliance on clay in architecture, writing and pottery sculptures.

The artworks of this period were precisely distinguished in the various motifs used to decorate the architecture. But it lacks perspective, with simple and limited colors such as white, blue and red only. Sometimes (Tempra) colors are used as a technique in some subjects, as in mosaics or decorative tiles. One of the most famous topics is scenes of wars and very realistic ritual sacrifices. They also depicted various characters, geometric figures, people, animals, and monsters in different positions. Some of these works contain texts from detailed and precise cuneiform writing. These works undoubtedly reflect a wonderful naturalness. A distinction can be observed between the affairs of the goddess and humanity. The king is often depicted in scenes of fierce grinding wars, banquets, private banquets, or the hunting profession. The king always appears as an erect and prominent figure and has a direct influence on the art scene.

Mosaic often appears as the most common style used in this style of painting. Where many wonderful works can be found in Ur tombs. In addition, the use of glazed bricks for decorative purposes in several structures. 


\section{THE EFFECT OF THE NATURAL ENVIRONMENT ON THE LIFE OF THE OLD IRAQI ARTIST}

The environment is the place where a person lives and dies and performs his various activities, as it affects his public and private behavior. The general trend towards others is cooperation among them on various issues and it is one of human behavior as it becomes social when it is related to the behavior of other people and is directed to their behaviors (Max, 1946, p. 64) There is familiarity and cooperation between them in order to accomplish a work, such as the state of flood and fire, and so on. As for the individual, the individual undertakes several activities to overcome environmental fluctuations that can cause him a dilemma, for example, or make him happy. There are different types of it, such as the desert and mountainous environment, the environment consisting of marshes and swamps, as well as the changing weather environment and social environment (Saliba, 1982, pp. 220-221).

Because these types of the environment must be studied in some detail when dealing with the style of an artist, and upon knowing the characteristics of these types of environment, it can be reached the real influence in this artist's style, that the emphasis has been settled on the importance of studying the interaction between object variables and ocean variables and finding relationships Common between them (AlShamaa, 1981, p. 141), However, the natural environment in which a person lives, the social environment, and the constructed environments such as architecture, including castles and various buildings that carry elements of a beautiful creative nature such as domes (Al-Fairooz Abadi, p. 177. Al-Bustani, p. 19) Arches of different sizes and types have been decorated with geometrical and floral motifs, and the compositions of which the artist practices his life and daily activities all affect his aesthetic composition, as nature presents him with several aesthetic aspects and elements that excite joy and pleasure (Muhammad Saeed, $1410 \mathrm{AH} /$ 1990, p. 259). Therefore nature is seen in shadow, light, life, death, vocal movements, calmness, rain, snowfall, roaring waterfalls, desert sandstorms, and many other things that give people a kind of excitement that makes them think about emulating them or expressing that with anything. Likewise, it is necessary for the artist to transform his experience into one of the expressions of color so that his artistic performance delivers him to deepening the human sense of the world and the things surrounding it (Journal of the Word, 1972, p. 4).

The life of a person is seen in the desert countryside, for example, characterized by its cruelty and drought, and the life of the ancient primitive man was dominated by the closest thing to it. Most of the desert population is nomadic, traveling from one place to another according to the sources of living such as water and pasture, and although the difficult lives of these people and their interest in living, they have also been distinguished by art, for example, in costumes, tattoos, and dyes, especially henna, in addition to sewing various kinds, embodying the heroic epics of kings, warlords and scenes The different hunting and representation of daily life as accomplished by the artists who lived in such an environment, he often sees flirting with them by reviving them with their paintings in which the environmental impact on them appears clearly evident, in addition to this that this environment represents their inherent heritage, They cannot transcend their society but rather try to interact with it because they are from it (that everyone has a motive that drives him to belong to a certain group of people and needs to appreciate, love and respect them for them. This is all done only by interacting with them and accepting the prevailing social norms, rules and behavioral norms that they have. We must call it (the social standards of behavior) (Al-Samarrai, 1988, p. 92).

Therefore, the artist must reconsider his environment and the surrounding soil and be faithful to his study of his community and present his faults and search for details of daily life, The changes, development, and monitoring of events that have occurred in order to sow the most beautiful ideas and the best images and create the appropriate atmosphere, and spread throughout its environment (the artist), the most wonderful of which he produced his ideas of useful real values that prevail in society and expel the false impurities that are exotic on him, so the environmental effects make the ancient artist think And that this thinking makes him to innovate and create to produce then a work with the effect of this environment that affected him and his feelings in its 
various forms (Ali, $1417 \mathrm{AH} / 1996 \mathrm{AD}, \mathrm{p} .243)$, ((It is certain though that no art can be established without thought, except God unless A form could be created without substance, or an image without subject ....)) (Ibrahim, p. 226).

Each artist has his own style (Ibn Manzur, p. 471), as he is considered one of the means of expression for him, as it is without a doubt a method that he adopts and takes, and is known to him and called by philosophers on how he expresses ideas through him and adopts various types of movement embodied in these ideas (Saliba, op. cit, P. 80) ((The method is the human being, and this means that the method is the formula, or authorship that charts one's qualities and attributes, and the doctrine that each of the writers goes about in authorship between his words and his images ... The style differs not only with the different writers, but also with different ages). Because each age has its own way of expressing feelings and thoughts in writing, photography or music, and every indigenous artist has his own way of all images, lines, colors, and sounds to express the meanings he envisions (Ibid). The metal of the method ... the expressive means that exist in the language that highlight emotional, voluntary, aesthetic and even social and psychological paradoxes, so they are exposed first and especially in the common spontaneous language before they appear in the artistic impact (Al-Sadi, p. 41. Bin Thurail, 2000, 43).

On the other hand, the dry method with a dull color, which lacks heat, does not leave any effect on the soul and does not move it, as in the simple natural method with emotional feelings. There is also, besides the methods of sinful art, a comprehensive method that works for every place and time, as it is a holistic method that expresses how it is affected Mind in nature. In this, it can be a perfect example of what the eternity has over the years as it appears, these methods differ radically with individuals and groups (Saliba, op. cit, p. 81). They are variable according to meditations and conditions because they were issued by the person himself or he used it however he wanted. So, each individual has his own style that may coincide or differ with his peers in some way, and since art is a characteristic of style, it is undoubtedly (a method of knowledge, the world of art or an approach to knowledge of value to man as is the world of philosophy or the world of science) (Reid, 1975, P. 17), Therefore, the artist is the one who uses this method to reach cognitive facts that can only be obtained through his research and artistic investigation, and thus he follows a certain method that is usually called by his name. The poet also has the attributes of the artist (as for poetry, it is an art in which the language is especially at the forefront, and the poet, listener, or reader cannot forget the language in which he is formulated) (Adman, p. 61. Jiro, 1964, p. 28 and beyond), and for this reason the poet (The jeweler of words), as this formulation is of a certain style that the poet takes, so that it is meant as sadness, joy or others. Therefore, the poet's style corresponds to the artist's style in terms of the way each of them expresses what he feels, according to his specialty (i.e. the difference in the expressive medium). According to that (the artistic activity itself is a form of intelligence) (Ibrahim, p. 226), then the artist's method and style stem from the fertile idea as well as the poet, the use of what is in his heritage is rewritten in his own style.

The style is not limited to poetry or art, but goes beyond the term in sociology and ethics to be applied to the approach of individuals and groups who take it in their work and from their saying the way of life and its meanings to launch it on the way the author coordinates his ideas, it is in this sense arrangement and harmony. It is undoubtedly the art of multiple and contrasting individuals and societies.

\section{XAMPLES OF NATURE IN ANCIENT IRAQI PAINTING}

The Iraqi environment has acquired since ancient times a distinguished and distinguished place in the heart of the ancient world, represented by the countries of the ancient Near East, as it is located in the southern part of the Asian continent (Baqer, 1986, p. 25). Running from the north to the south of the Tigris and Euphrates, which are two great 
rivers, twins of great importance, as is the status of the Nile in Egypt (George, 1984, p. 23), and they played a major role in the movement of internal transportation, encouraging trade and military campaigns (Figure 3)

and transferring their influence to the neighboring regions (AlDabbagh, 1983, p. 21) Through them the greatest civilizations emerged and became the most important global regions in the progress of irrigation, land investment and benefit from the surrounding natural environment (Suse, 1946, p. 3). This natural environment encouraged the ancient Iraqi painter to employ its vocabulary in various works that deal with important issues such as being religious, political, social, military or daily life. It reached its climax in the second millennium BC with formulas of holographic, prominent and deep sculptures, cylindrical seals and pottery vessels, and their decoration, and paintings of beautiful artistic drawings that express only high taste, high skill and accuracy in implementation, which was inspired by the old Iraqi artist from his environment, which is characterized by a philosophical approach to a particular spiritual interpretation of interpretation It is of high creative value, and aesthetic touches that the artist achieves with poetic rapprochement between very familiar objects. It is extracted from its natural state to turn it into a variety of formal metaphors with creative horizons that start with the mediation of the person himself, And asserting its right to transcend the natural environment from which all its topics are devised according to new aesthetic standards, represented by artistic and literary exploits, The one who was born out of hands made of mud figures and creative pens represented from the edges of reeds that vary in sizes to create legends and stories, with a cuneiform character with a realistic image identical to him to be called the cuneiform, and by combining it with other letters of his kind a word is created from which sentences and then texts of balanced encyclopedic laws are created And a rigorous scientific value very accurate to feed humans on the face of the globe with an uninterrupted flow of knowledge and to this day science tries to find out its secrets. Thus, the old Iraqi artist excelled through his direct expression of visual perceptions, whether they were shapes, colors, or elements that are in the vicinity of his natural and constructed environment, such as military campaigns, hunting campaigns in forests and marshes, and the alignment of rivers, desert and religious and political decrees. These numerous artworks show the features of the natural environment, such as sacred palms, pine trees, weeds, reeds, papyrus, birds, various wild animals, as well as fish. The following are various scenes of the effects of the natural environment in ancient Iraqi art. The researcher has devoted to the sacred palm tree being part of the environment surrounding the ancient Iraqi artist:

To record his history and daily events in expressive formulas with a variety of aesthetic implications (Figure 4). Most of his topics were derived from religious beliefs and political life, but their impact was clear on the nature of art in the ancient Iraqi heritage, where religious and political belief is the main manifestation of these arts, bearing its characteristics, including the meanings and

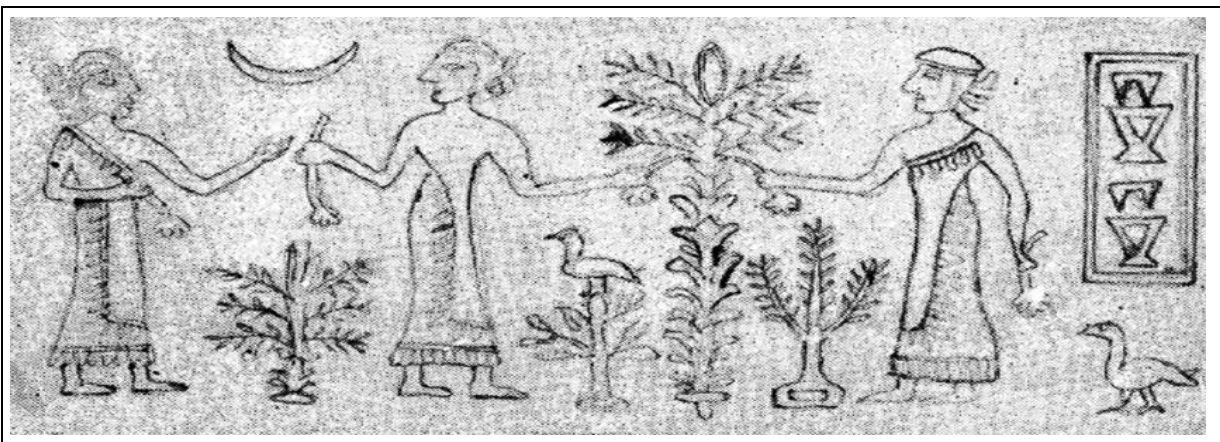

Figure 4 represents the inscription, the sacred palm tree, the remains of the Sumerian inscriptions of the palm, the Sumerian era) Reddy, J., Assyrian sculpture, London, 1983. 
psychological values and social implications, Through this, the first Iraqi artist was able to employ the different materials, means and concepts of his rich heritage to create authentic artistic experiences and presented a set of values and concepts that can be discovered in the numerous artistic, sensory, symbolic, functional and expressive artworks that he created linked to all elements of the artwork, such as expressive composition, techniques, different materials, expressive lines, and colors In addition, ideas

that express original creativity parallel the distinguished and distinguished place occupied by Iraq during that period. And it can be linked to those artistic

activities through drawings that adorn temples and palaces that have undoubtedly achieved important steps in establishing artistic rules, in a way that suits the spiritual and cultural composition, and this was evident clearly through his various drawn works and formations in the scenes of those speaking murals. The most prominent of them (The Palm), (Figure 5) which has gained a prominent place throughout its history and has become a striking example of

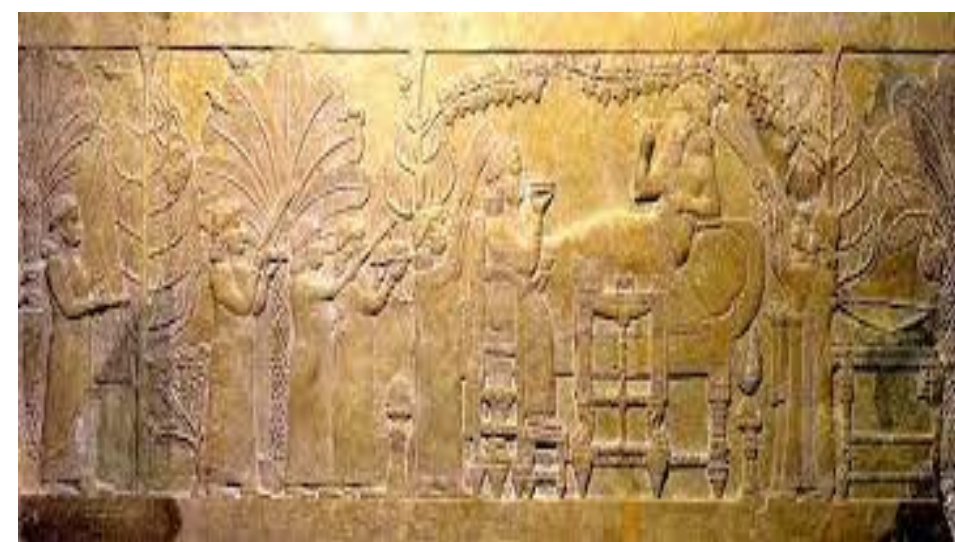

Figure 5: A royal family session in the date palm farms Nun, Astrid, daily life in the ancient East, 2006, p. 20. generosity and generosity.

Naturalism played a distinct and tangible role in the lives of the ancient Iraqis (Figure 5), and it was mentioned in many cuneiform texts and their names and parts of palm leaves and fiber and its uses in many industries. Palm and its transactions, and imposing a fine on anyone who neglects caring for the palm grove or cuts a palm tree. Throughout the ages, it was a source of inspiration for many artists as a distinctive decorative element that reflects the Iraqi natural environment that was in the old days, where it was depicted in many of its artistic remains of stone sculptures, ivory and cylindrical seals (Fig. 6).

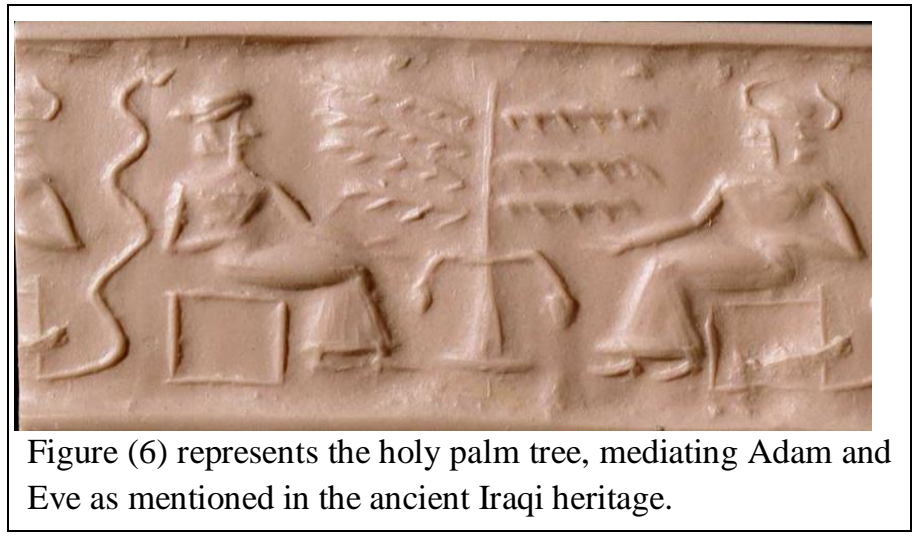


The decoration accompanied its art of photography since ancient Egyptian and Mesopotamian times, where the Egyptian motifs appeared in the architecture of columns decorated with palm fronds, papyrus or lotus flower. Egyptian floral motifs also appear in the furniture discovered in Tutankhamun's tomb inlaid jewelery. There are decorative ornaments inspired by the animal such as scarab and eagles spreading their wings, and heads of the seven, with the exception of ornaments decorated with geometric motifs that are often frames of the previous topics. In Mesopotamia, architectural motifs are visible in the upper bed sheets on the walls, and in ribbed niches that cover the architectural façades. The motifs are visible on Sumerian pots, on the walls of Assyrian temples and palaces, and on the facades of Babylonian buildings, which are prominent colored ceramic figures depicting deities in the form of mythical animals.

And it is confirmed here on the inspiration of (plant forms) from the natural environment, which represents the title of Mesopotamia and a symbol of Sumeria, Akkadian, Babylon, and Assyria in the past, which is the sacred tree and (the tree of life) they have, and is a symbol of the giving of land and agricultural wealth in addition to that (spike), which represents some of these considerations. Thus, all of this influences the natural (plant) environment on the concept of

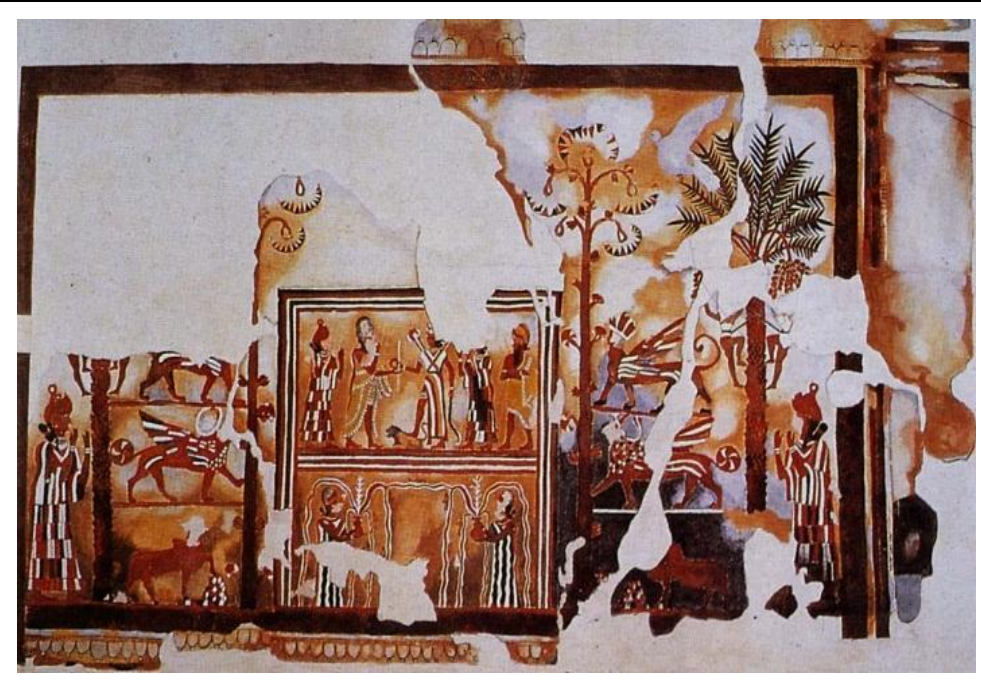

Figure (7) represents a mural depicting the installation of King Zamri Lm. Mortkat, Anton, Art in Ancient Iraq, Form (49B), p. 241. symbolism in the thinking of the artist and the ancient Iraqis (Figure 6).

Among the aesthetic studies that have emerged, is (morphology of the forms), which means the study of the structure of things or their forms (and it became clear from what is also distinguished in the reigns of ancient art history, the creations presented by ancient Iraqi artists, some of which formed a wonderful aesthetic of the forms of natural beings (Living and non-living), by modifying and installing these figures into vocabulary, symbols, and decorative units that had their (religious-ritual) or (earthly-political) purposes that became known to all. Among what is unknown to the specialists and researchers is the type of tree that developed a wonderful morphological change from the original tree and which took two important and major sites on both sides of the central part (for the walls of the inauguration of King Zemri Lam) in Mary in the ancient Babylonian era (2003 - 1594 BC). The date of the mural's implementation dates back to the year (1760 BC to the 18th century BC) from the time of King Zumri Lam, on which the main topic of the mural revolves around, while crowning a king over the city of Mary. Other scenes that represent the activities of the ancient kings of Iraq are hunting Or military campaigns or hiking, Figures $(8,9,10,11)$. 


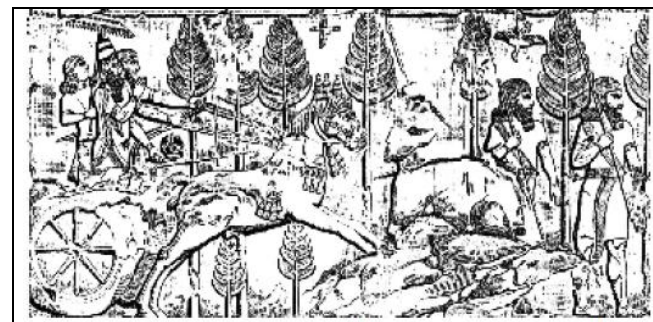

Figure 8. A sculptural memorial to the Assyrian king Shervukin (Sargon) Alaşuri represents his royal cart in a mountainous environment fraught with oak and pine trees during his eighth campaign on Urartu. Botta and Flandin, Monument de Ninive II, 88 .

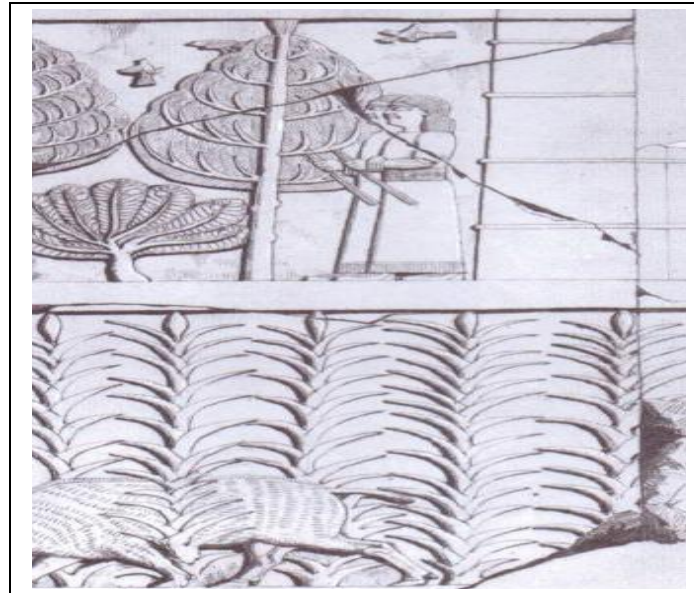

Figure (9) contains two parts, the upper is a natural environment in which a group of birds appears above the cypress and pine trees and hunters, and at the bottom is a marshes environment and a wild boar grazing between reeds and papyrus (Nineveh around $645 \mathrm{BC}$ ), American Oriental Series: 88, printed in the USA, New Haven, Connecticut, 2005, p. 59.

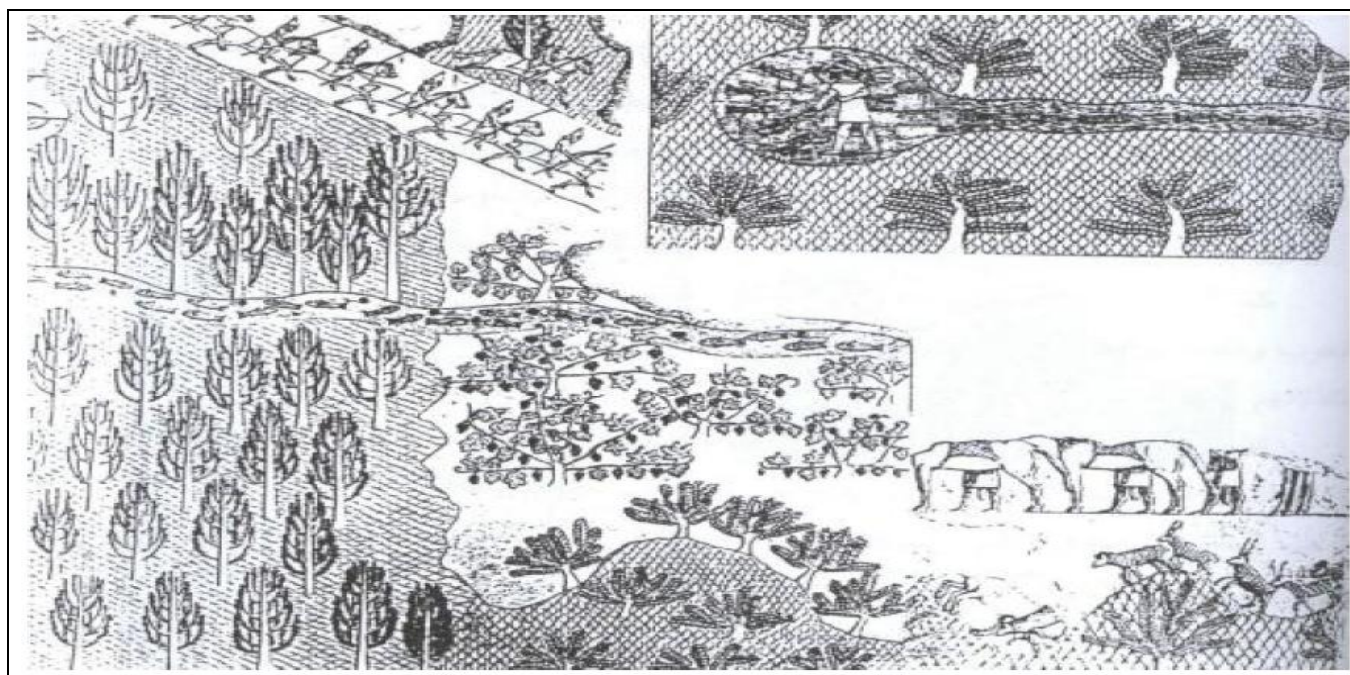

Figure 10. Scenes from the era of Sin, brother Iriba (Sennacherib), the most prominent sculptor in which the environment of the Levant region is represented by representing tree varieties such as vines, olive trees and pine trees as well as the highlands, coasts and islands of the Mediterranean (the plant distribution of the region.(Botta, op. cit). 


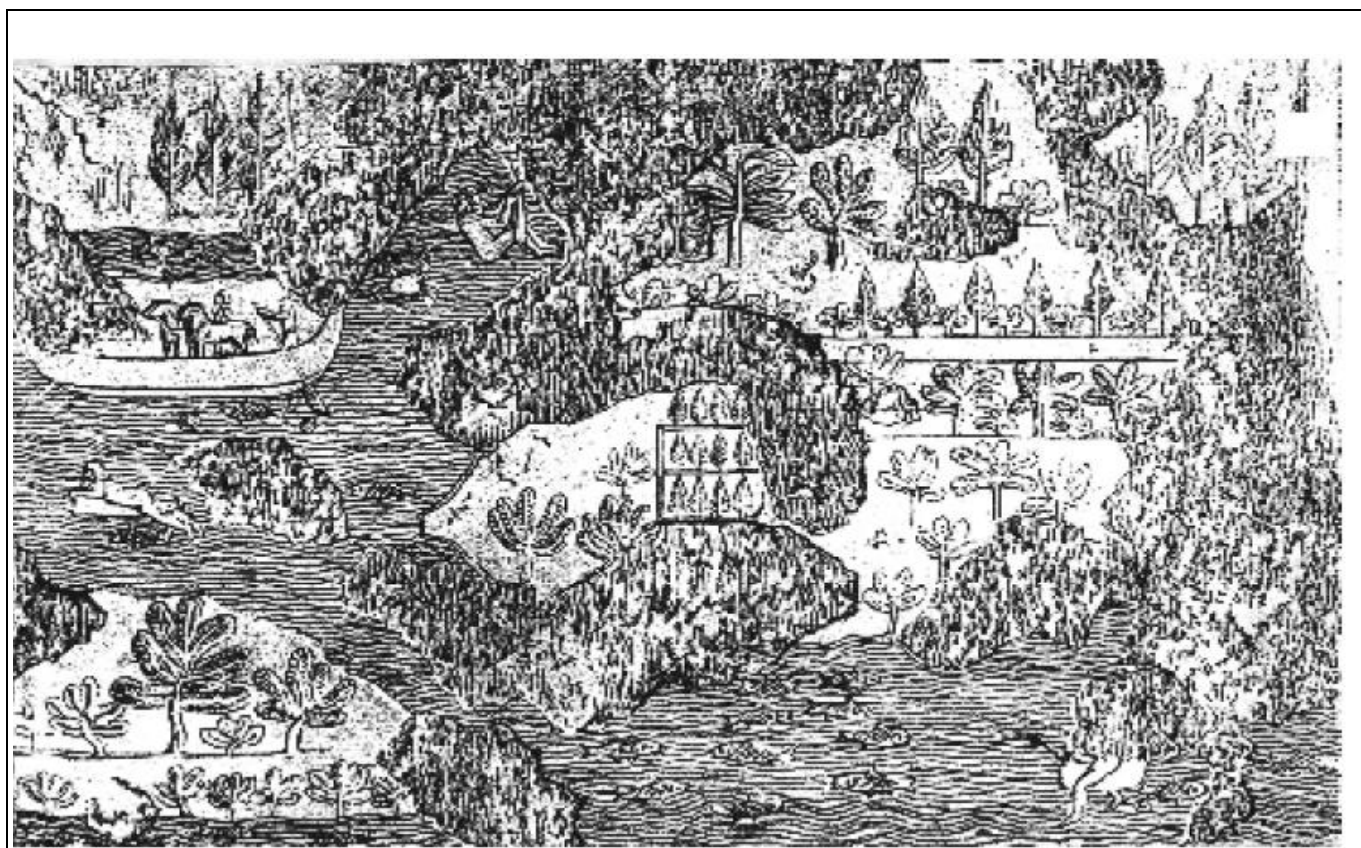

Figure 11. Scenes from the coastal areas overlooking the Mediterranean Sea, some islands, fish, marine animals and the means of transport for the navy. After that, the painter distributed different types of trees in different areas of the scene. Continino, George: Daily Life in the Land of Babylon and Assyria, translated by Salim Taha Al-Takriti, House of Cultural Affairs General, Second Edition, Baghdad, 1986, p. 392.

\section{CONCLUSION}

After completing the milestones of this study plan, it appears that it has opened up great prospects for questions about the aesthetics of nature in the ancient Iraqi painting. This study attempted to answer it. The depiction of nature in the works of ancient Iraqi art was repeated in the scenes of sculptures of the palaces of the ancient kings of Iraq during their successive eras, confirming the widening of the political map of their kingdoms (6000 - 539 BC), They moved the natural environment that they found in the wide open areas to be implemented in the form of sculptures and royal gardens that include all kinds of trees, plants, animals, birds and fish in mountainous areas, plains, desert and various marsh environments. To be displayed in their country in an effort to highlight the manifestations of strength and greatness that their country has reached, as well as to give fright to the hearts of their enemies. Through which the following results were derived:

A. It appeared that there are several drawings embodied by the old Iraqi artist to show the aesthetic of nature, which directly affected the life of the old Iraqi painter and then on his various artistic achievements for different and successive eras.

B. No artwork by the ancient Iraqi artist was devoid of one of the elements of the natural environment, being the direct driver of his feelings and feelings, in addition to the important economic aspect that it provides. Including pine trees, rice, and fruit trees such as vines, grapes, and amanus mountain plants.

C. Environmental elements such as plants, animals, birds, and water were repeated in most artworks.

D. The old Iraqi artist often uses realistic style, then abstract in drawings, sculptures, or cylindrical seals. 


\section{SOURCES:}

1. Adman, European, (n.d).Arts and Humans, a brief introduction to aesthetics, Misr Printing House, Cairo.

2. Al-Dabbagh, Taqi, (1983).Iraq in History, Freedom House Printing, Baghdad.

3. Al-Jadir, Walid,(1985). Al-Amara until the Era of the Dynasties in the Iraq Civilization, Freedom House Printing, Baghdad.

4. Al-Kalima Magazine,(1972).1st Issue, Fourth Year, January, Dar Al Saah Press, Baghdad.

5. Al-Masdi, Abd al-Salam,(n.d). Stylistics and Method, The Arab Book House, 3rd Edition.

6. Al-Samarrai, Hashem Jasim,(1988/1408AH). Introduction to Psychology, Munir Press.

7. Al-Shamaa, Naima,(1981). Personality, (Theory, Evaluation, Research Methods), Baghdad University Press, Baghdad.

8. American Oriental Series: 88,(2005). printed in the USA, New Haven, Connecticut.

9. Baqer, Taha,(1986). Introduction to the History of Ancient Civilizations, Baghdad.

10. Baqer, Taha,(2009). Introduction to the History of Ancient Civilizations, Al-Warraq Publishing House, Beirut.

11. Bin Thurail, Adnan,(2000). Text and Stylistics between Theory and Practice, from the publications of the Arab Union, Union of Arab Writers Press, Damascus.

12. Botta and Flandin,(n.d) Monument de Ninive II, 88.

13. Continino, George (n.d). Daily Life in the Land of Babylon and Assyria, translated by Salim Taha Al-Takriti, House of Cultural Affairs

14. Hati, Philip,(1958). History of Syria, Lebanon and Palestine, translation: George Haddad and Abdel-Karim Raafat, House of Culture, Beirut.

15. General,(1986). $2^{\text {nd }}$ Edition, Baghdad.

16. George, Rowe,(1984). The Ancient Iraq, translated by Hussein Alwan Hussein.

17. Giro, Pierre,(1994). Stylistics, Trans: Dr. Munther Ayashi, Development Rehabilitation Center, Dar AlComputer for Printing - Aleppo, $2^{\text {nd }}$ edition.

18. Ibn Manzur (Muhammad Bin Makram Bin Ali Abu Al-Fadl Jamal Al-Din Bin Manzoor Al-Ansari Al-Ruwa'fi Al-Afriqi (711 AH) - (1311 AH / 1955 AD). Lexicon of the Arabs, Dar Sader Beirut, Lebanon.

19. Ibrahim, Zakaria,(n.d) artist and person, Gharib Library, Cairo.

20. Ismail, Bahija,(1985). Encyclopedia of Iraq Civilization.

21. Kassar, Akram Muhammad Abd,(1988). "Reading in Prehistoric Times in Ancient Iraq," Arab Horizons, No. 4, Thirteenth Year.

22. Max, Weber.(1946). Essays on sociology. New York.

23. Muhammad Ali, Muhammad Abd al-Latif,(1977). History of Ancient Iraq Until the End of the Third Millennium BC, Alexandria, Egypt.

24. Muhammad Saeed, Abu Talib, (1410 AH-1990 AD). Technical Psychology, Higher Education Press, Mosul, Mosul.

25. Murkutat, Anton,1975). Art in Ancient Iraq, translation: Issa Salman and Salim Taha Al-Takriti, Baghdad: AlAdeeb Al-Baghdadiya Press.

26. Murkutat, Anton,(1975). Art in Ancient Iraq, translation: Issa Salman and Salim Taha Al-Takriti, Baghdad: AlAdeeb Al-Baghdadiya Press.

27. Nunn, Astrid,(2006). The Old Orient, Mainz, German.

28. Raafat Ali, (1417 AH / 1996).Architectural Creativity Trilogy, Al-Shorouk $1^{\text {st }}$ Press.

29. Reade. Julian (1963). Assyrian Sculpture, London.

30. Reid, Herbert,(1975). Art and Society, Dar Al-Qalam, Beirut.

31. Rowe, George,(1986). The Ancient Iraq Book, translation: Hussein Alwan, $2^{\text {nd }}$ edition.

32. Saeed, Muayyad,(1985). "Architecture from the Age of the Dawn of Dynasties to the End of the Modern Babylonian Era" in the Civilization of Iraq, Part 3, Chapter Two, Second Topic, Freedom House Printing, Baghdad. 
33. Saliba, Jamil,(1982). Philosophical Dictionary, Lebanese Book House, School Library, Beirut, Lebanon.

34. Susah, Ahmad,(1978). Features of the Ancient History of Iraqi Jews, Asaad Press, Baghdad, 1st edition.

35. Susah, Ahmed,(1946). The Development of Irrigation in Iraq, Baghdad.

36. Al- Bostani, Boutros,(n.d). ocean circumference.

37. Al-Fairooz Abadi, (2005AD / 1426H) Al-qamoos Al-Moheet, Al-Resala Foundation.

38. https://fr.wikipedia.org/wiki/Fichier:Warka_vase_(background_retouched).jpg

39. https://upload.wikimedia.org/wikipedia/commons/6/6e/UrukHead.jpg

40. https://www.alamy.com/purchase/cust-order-confirm.aspx 